\title{
Antifungal Activity of Essential Oil Isolated from Ocimum gratissimum L. (eugenol chemotype) against Phytopathogenic Fungi
}

\author{
Terezinha de Jesus Faria ${ }^{1 *}$, Rafael Sottero Ferreira ${ }^{1}$, Lidiane Yassumoto ${ }^{2}$, José Roberto \\ Pinto de Souza ${ }^{3}$, Noemia Kazue Ishikawa ${ }^{4}$ and Aneli de Melo Barbosa ${ }^{2}$ \\ ${ }^{1}$ Departamento de Química; CCE; ${ }^{2}$ Departamento de Bioquímica; CCE; ${ }^{3}$ Departamento de Agronomia; CCA; \\ ${ }^{4}$ Departamento de Biologia Geral; CCB; Universidade Estadual de Londrina C. P. 6001; 85051-970; Londrina - \\ PR - Brasil
}

\begin{abstract}
An investigation of antifungal activity of the essential oil obtained by steam-distillation (1.1\% w/w) of the aerial parts of Ocimum gratissimum and of an ethanolic extract from the steam-distillation residue was carried out using the agar diffusion method. The results revealed that the essential oil inhibited the growth of all fungi tested, including the phytopathogens, Botryosphaeria rhodina, Rhizoctonia sp. and two strains of Alternaria sp., while the extract from the residue was inactive. The essential oil was subjected to TLC bioautography used to detect fungitoxic constituents. The compound that showed antifungal activity was isolated and identified as eugenol. GC/MS analysis showed that eugenol was the main constituent of the essential oil studied. The antifungal activity of eugenol was evaluated against a species of Alternaria isolated from tomato $\left(\mathrm{A}_{1}\right)$ and Penicillium chrysogenum. The minimal inhibitory concentrations of eugenol were 0.16 and $0.31 \mathrm{mg} / \mathrm{disc}$ for Alternaria sp. $\left(\mathrm{A}_{1}\right)$ and $P$. chrysogenum, respectively.
\end{abstract}

Key words: Ocimum gratissimum, essential oil, antifungal activity, eugenol, phytopathogenic fungi

\section{INTRODUCTION}

Ocimum gratissimum, originating in the Orient, is widespread throughout tropical countries including Brazil, where it is popularly known as "alfavacão, alfavaca and alfavaca-cravo" (Lorenzi and Matos, 2002). This species is used in traditional medicines in South America and Africa for a variety of therapeutic purposes which includes its use in treating bacterial infections, diarrhoea, diabetes (Aguiyi et al. 2000), respiratory-tract infections, pneumonia, fever and coughs (Corrêa, 1926). Evaluation of the biological activities revealed that extracts of $O$. gratissimum exerted anti-diarrheal effects in experimental animals (Onajobi, 1986; Offiah and Chikwendu, 1999), showed high antiviral indices against HIV-1 and HIV-2 (Ayisi and Nyadedzor, 2003) and hypoglycemic activity in rats (Aguiyi, 2000). Atal et al. (1986) investigated the immunobiological activity of certain medicinal plants and observed that extracts of $O$. gratissimum appeared to improve the phagocytic function without affecting the humoral or cell-mediated immune system.

The essential oil of this species also presented interesting activities such as insecticidal (Kéita et al., 2001), antibacterial (Janssen et al., 1989;

\footnotetext{
${ }^{*}$ Author for correspondence
} 
Nakamura et al., 1999; Cimanga et al., 2002; Ngassoum et al., 2003), antifungal (Dubey et al., 2000), and as a relaxant on isolated ileum from guinea pig (Madeira et al., 2002). The essential oil of $O$. gratissimum and its main component eugenol were efficient in inhibiting eclosion of Haemonchus contortus, a gastrointestinal parasite of small ruminants (Pessoa et al., 2002).

This paper describes the results of the evaluation of the antifungal activity of the essential oil obtained by steam-distillation of aerial parts of Ocimum gratissimum, the ethanolic extract from the steam-distillation residue, and the purified active compound eugenol, using the agar diffusion method and TLC bioautographic technique.

\section{MATERIALS AND METHODS}

\section{General \\ ${ }^{1} \mathrm{H}-\mathrm{NMR}$ (200MHz) and ${ }^{13} \mathrm{C}-\mathrm{NMR}$ (50.3MHz)} spectra were recorded on a Bruker Spectrometer. Chemical shits were $\delta$ in (ppm) using tetramethylsilane as st,andard. IR spectra were obtained with a Shimadzu FTIR Model 8300 6AD, using $\mathrm{KBr}$ pellets. GC/MS-capillary gas chromatography was performed in a Shimadzu GC-17A chromatography coupled to a Shimadzu GC/MS-QP5000 using a DB-1 capillary column (cc, $30 \mathrm{~m} \mathrm{x} 0.25 \mathrm{~mm}$ ), temperature programmed at $60{ }^{\circ} \mathrm{C}$ per $4 \mathrm{~min}$ over the range $60-250{ }^{\circ} \mathrm{C}$ at 10 ${ }^{\circ} \mathrm{C} / \mathrm{min}$, and $250-330{ }^{\circ} \mathrm{C}$ at $20{ }^{\circ} \mathrm{C} / \mathrm{min}$. Mass spectra were compared with spectra from the literature (Saito et al., 2004).

\section{Plant material}

Aerial parts of $O$. gratissimum were collected at the Horto de Plantas Medicinais, Department of Agronomy of the State, University of Londrina (Paraná). A voucher specimen (36554) has been deposited at the Herbarium of this University.

\section{Steam distillation}

The volatile oil was extracted from dried aerial parts of $O$. gratissimum by steam-distillation (100 $\mathrm{g}$ of plant material) for $5 \mathrm{~h}$ using a Clevenger apparatus. The distillate was extracted with dichloromethane, and the resulting extract dried over anhydrous sodium sulfate and concentrated under reduced pressure yielding $1.1 \mathrm{~g}$ of essential oil.
Extraction of the residue following steamdistillation

The plant material of, steam distillation was dried for three days and extracted with ethanol at room temperature. After filtration, the solvent was removed by rotary evaporation under reduced pressure yielding $7 \mathrm{~g}$ of extract.

\section{Microbial cultures and growth conditions}

The fungi used in the agar diffusion method were: Aspergillus niger, Penicillium chrysogenum, and the phytopathogens: two strains of Alternaria sp. (isolated from tomato and carrot and denoted as $\mathrm{A}_{1}$ and $\mathrm{A}_{2}$, respectively), Botryosphaeria rhodina and Rhizoctonia sp. Cultures of these fungi were grown on agar plate at $28{ }^{\circ} \mathrm{C}$ and maintained with periodic sub-culturing at $4{ }^{\circ} \mathrm{C}$. All microorganisms were derived from stock cultures from the Department of Biochemistry of the State University of Londrina. The fungi used in the TLC bioautography technique was Cladosporium herbarum (NRRL 2175), maintained on agar slopes of PDA at $4{ }^{\circ} \mathrm{C}$. The microorganism was derived from the Department of General Biology of the State University of Londrina.

\section{Assay of antifungal activity}

Antifungal activity of the essential oil and the extract of the steam-distillation residue was evaluated by the agar diffusion method. The test was performed in sterile Petri dishes $(90 \mathrm{~mm}$ diameter) containing potato-dextrose-agar (PDA) medium $(20 \mathrm{~mL})$. The samples for evaluation were dissolved in ethyl acetate and aliquots at different concentrations applied to sterile paper discs $(8 \mu \mathrm{L}$ of solution per Whatmann No. 1 disc of $5 \mathrm{~mm}$ diameter, resulting in final concentrations of 7.50, $4.12,0.08,0.04,0.02$ and $0.01 \mathrm{mg} / \mathrm{disc}$ of the essential oil; $8 \mu \mathrm{L}$ of solution/disc of extract of steam-distillation residue and 4.40, 0.62, 0.31, 0.16 and $0.08 \mathrm{mg} / \mathrm{disc}$ of eugenol). The discs were placed on the surface at the center of agar plates inoculated with a fresh fungal suspension (one microorganism per Petri dish). The Petri dishes were then incubated at $28{ }^{\circ} \mathrm{C}$ for $48 \mathrm{~h}$, followed by the measurement of the diameters of zones of inhibition. Inhibition of fungal growth was measured as zone diameters $(\mathrm{mm})$ at 4-equidistant points taken from the centre of the inhibition zone, and the average value taken. All experiments were carried out in triplicate and the reported data 
represents average values \pm SD. Ethyl acetate was used as a control.

\section{TLC bioautography}

Essential oil was applied to 2 TLC plates and developed in dichloromethane as solvent. One plate was used as the reference chromatogram, and the other for bioautography. A spore suspension of C. herbarum was sprayed over the developed TLC plate, which was, in turn, incubated at $28{ }^{\circ} \mathrm{C}$ under humid conditions for 3 days (Homans and Fuchs, 1970). The inhibitory zones observed were then correlated with the spots seen on the T,LC plate used as the reference chromatogram, and visualized under UV light at $254 \mathrm{~nm}$.

\section{Isolation and identification of the major constituent}

The essential oil obtained as described above $(0.8 \mathrm{~g})$ was chromatographed on a column of silica gel and eluted with a gradient of hexanedichloromethane $(95: 5,85: 15$ and $60: 40)$ to $100 \%$ dichloromethane. One hundred and sixty five fractions each of $20 \mathrm{~mL}$ were collected and analysed by TLC to yield seven groups (G:1-7). Group G-2 (fractions 18-78) eluting with hexane was subjected to preparative TLC and eluted with dichloromethane. The material obtained was purified by flash chromatography as described by Still et al., (1978) using a mixture of petroleum ether/ethyl acetate (95:5) as eluent. Thirty fractions $(5 \mathrm{~mL})$ were collected. Fractions $13-25$ contained the active compound $(0.1 \mathrm{~g})$, identified as eugenol.

\section{RESULTS AND DISCUSSION}

The present study showed that the essential oil was obtained in a yield of $1.12 \%(\mathrm{w} / \mathrm{w})$ from the dried aerial parts of $O$. gratissimum. Vieira et al. (2001) reported significant variations in the range and content of twelve accessions of $O$. gratissimum $(0.29-1.66 \%)$. Studies focused on characterizing the volatile oil from this species revealed variations in its chemical composition. Based upon the dominant constituents, volatile oils could be divided into various chemotypes: eugenol, thymol, citral, ethyl cinnamate, linalol or geraniol (Dubey et al., 2000; Vieira et al., 2001). The chemical composition also showed a great variation during the daytime (Silva et al., 1999). In the present work, the analysis by GC-MS showed eugenol to be the major constituent of the essential oil of $O$. gratissimum obtained from the Londrina region (Fig. 1). The essential oil and residue of steamdistillation were tested for antifungal activity. The steam-distillation residue was found to be inactive against all of the fungi tested, while the essential oil inhibited the growth of the six fungi screened. The results summarized in Table 1 showed that the essential oil produced a zone diameter of inhibition of 9-to-55 $\mathrm{mm}$ depending on the fungus tested. It was, however, observed that the growth of Alternaria sp., isolated from tomato $\left(\mathrm{A}_{1}\right)$, was most sensitive with a zone diameter of inhibition of $9 \mathrm{~mm}$ at the lowest concentration $(0.01 \mathrm{mg} / \mathrm{disc})$ tested.

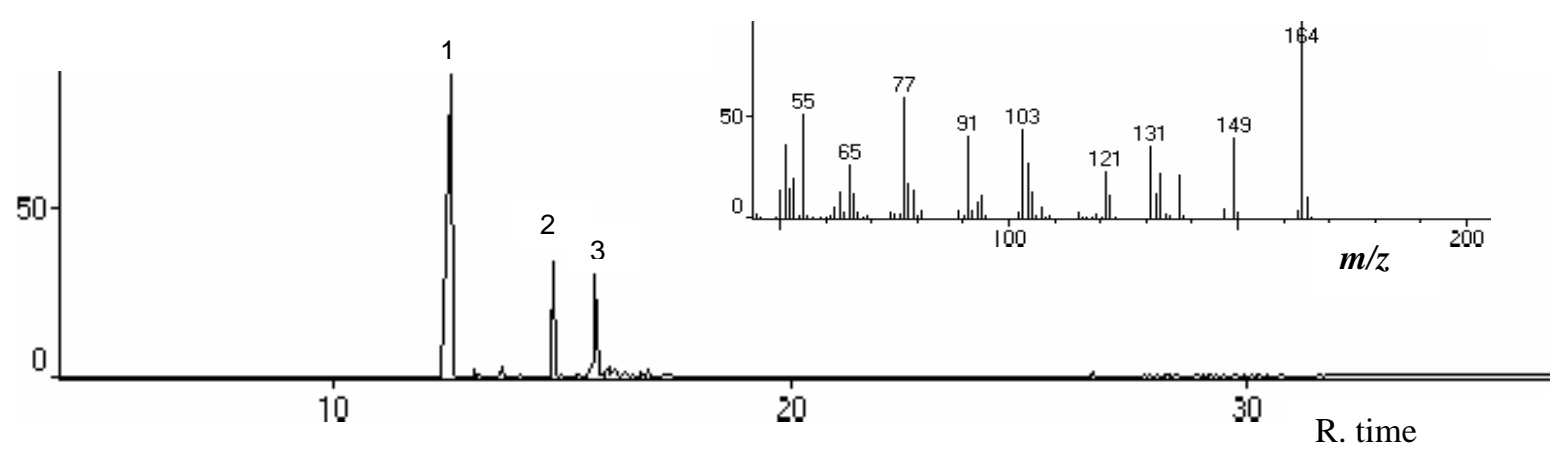

Figure 1 - Chromatogram of essential oil of $O$. gratissimum and mass spectrum of major constituent (peak 1, eugenol). 
$\underline{\text { Table } 1 \text { - Antifungal activity of essential oil as determined by agar diffusion method. }}$

\begin{tabular}{|c|c|c|c|c|c|c|c|}
\hline \multirow{3}{*}{ Microorganism } & \multicolumn{7}{|c|}{ Concentrations (mg/disc) } \\
\hline & 0.01 & 0.02 & 0.04 & 0.08 & 4.12 & 7.50 & Control \\
\hline & \multicolumn{7}{|c|}{ Inhibition zone $(\mathrm{mm})$} \\
\hline Alternaria $\mathrm{sp}\left(\mathrm{A}_{1}\right)$ & 9 & 9 & 8 & 12 & 8 & 55 & 0 \\
\hline Alternaria $\mathrm{sp}\left(\mathrm{A}_{2}\right)$ & 0 & 0 & 0 & 0 & 36 & 52 & 0 \\
\hline Botryosphaeria sp & 0 & 0 & 0 & 0 & 23 & 38 & 0 \\
\hline Aspergillus niger & 0 & 0 & 0 & 10 & 32 & 53 & 0 \\
\hline P. chrysogenum & 0 & 0 & 0 & 0 & 45 & 48 & 0 \\
\hline Rhizoctonia sp & 0 & 0 & 0 & 10 & 41 & 41 & 0 \\
\hline
\end{tabular}

The essential oil was examined by the TLC bioautography technique (Homans and Fuchs, 1970) using Cladosporium herbarum as the test fungus. One antifungal spot was observed at $R_{f}$ 0.43 . The active compound was isolated and identified as eugenol by spectral analysis using ${ }^{1} \mathrm{H}-$ and ${ }^{13} \mathrm{C}-\mathrm{NMR}$, IR and GC/MS, and by comparison with literature values (Saito et al., 2004). Antifungal activity of eugenol was evaluated by the agar diffusion assay against Alternaria sp. $\left(\mathrm{A}_{1}\right)$ and $P$. chrysogenum. The minimal inhibitory concentrations of eugenol were 0.16 and $0.31 \mathrm{mg}$ for Alternaria sp. $\left(\mathrm{A}_{1}\right)$ and $P$. chrysogenum, respectively (Table 2 ).

Table 2 - Antifungal activity of eugenol as determined by agar diffusion method

\begin{tabular}{cccccccc}
\hline & \multicolumn{7}{c}{ Concentrations (mg/disc) } \\
\cline { 2 - 8 } Microorganism & 0.08 & 0.16 & 0.31 & 0.62 & 4.40 & Control & 3.73 \\
\cline { 2 - 8 } & 0 & 13 & 13 & 16 & 23 & 0 & 25 \\
\cline { 2 - 8 } & 0 & 0 & 7 & 15 & 51 & 0 & 48 \\
\hline Alternaria $\mathrm{sp}\left(\mathrm{A}_{1}\right)$ & 0 & \multicolumn{7}{c}{ Inhibition zone $(\mathrm{mm})$} \\
P. chrysogenum & 0 &
\end{tabular}

\section{CONCLUSIONS}

The constituent present in the essential oil of $O$. gratissimum responsible for antifungal activity was not present in the steam-distillation residue. The essential oil of $O$. gratissimum from the Londrina region obtained with a yield of $1 \%$ $(\mathrm{w} / \mathrm{w})$ represented eugenol as the major constituent. Eugenol was the compound responsible for antifungal activity of the essential oil of $O$. gratissimum. Essential oil of $O$. gratissimum showed antifungal activity against phytopathogenic fungi such as Botryosphaeria rhodina and Alternaria spp. This is the first report on this property of the essential oil of $O$. gratissimum. The results demonstrated the potential application of $O$. gratissimum essential oil in agriculture as first observed by Kéita et al. (2001) with $O$. gratissimum from Africa.

\section{ACKNOWLEDGEMENTS}

The authors gratefully acknowledge CNPq, Fundação Araucária (Paraná), and CPG-UEL.

\section{RESUMO}

O óleo essencial resultante da destilação por arraste a vapor das partes aéreas de Ocimum gratissimum e o extrato etanólico obtido do resíduo da destilação foram avaliados quanto à atividade antifúngica, utilizando-se o método de difusão em agar. $O$ óleo essencial inibiu o crescimento de todos os fungos testados, incluindo os fitopatogênicos Botryosphaeria rhodina e duas espécies de Alternaria sp, enquanto que o extrato do resíduo da destilação não apresentou atividade. O óleo essencial foi, então, submetido ao método de bioautografia em TLC para detecção do composto ativo. $\mathrm{O}$ componente ativo foi isolado e identificado através da análise por cromatografia 
gasosa acoplada à espectrometria de massas como o eugenol, constituinte majoritário do óleo estudado. Ensaios de atividade antifúngica revelaram a atividade do eugenol contra Alternaria isolada de tomate $\left(\mathrm{A}_{1}\right)$ e Penicillium chrysogenum. As concentrações inibitórias mínimas foram 0,16 $\mathrm{mg} /$ disco e $0,31 \mathrm{mg} /$ disco para Arternaria $\mathrm{sp}\left(\mathrm{A}_{1}\right)$ e $P$. chrysogenum, respectivamente.

\section{REFERENCES}

Aguiyi, J. C.; Obi, C. I.; Gang, S. S and Igweh, A. C. (2000), Hypoglycaemic activity of Ocimum gratissimum in rats. Fitoterapia, 71, 444-446.

Atal, C. K.; Sharma, M. L.; Kaul, A. and Khajuria, A. (1986), Immunomodulating agents of plant origin, I: Preliminary screening. Journal of Ethnopharmacology, 18, 133-141.

Ayisi, N. K. and Nyadedzor, C. (2003), Comparative in vitro effects of AZT and extracts of Ocimum gratissimum, Ficus polita, Clausena anisata, Alchornea cordifolia, and Elaeophorbia drupifera against HIV-1 and HIV-2 infections. Antiviral Research, 1766, 1-9.

Cimanga, K.; Kambu, K.; Tona, L.; Apers, S.; Bruyne, T.; Hermans N.; Totté, J.; Pieters, L. and Vlietinck, A. J. (2002), Correlation between chemical composition and antibacterial activity of essential oils of some aromatic medicinal plants growing in the Democratic Republic of Congo. Journal of Ethnopharmacology, 79, 213-220.

Corrêa, M. P. (1926), Dicionário das Plantas Úteis do Brasil e das Exóticas Cultivadas. Rio de Janeiro: Imprensa Nacional.

Dubey N. K.; Tiwari, T. N.; Mandin, D.; Andriamboavonjy, H. and Chaumont, J. P. (2000), Antifungal properties of Ocimum gratissimum essential oil (ethyl cinnamate chemtype). Fitoterapia, 71, 567-569.

Homans, A. L. and Fuchs, A. (1970), Direct bioautography on thin-layer chromatograms as a method for detecting fungitoxic substances. $J$. Chromatogr., 51, 327-329.

Janssen, A. M.; Scheffer, J. J. C.; Ntezurubanza, L. and Svendsen, A. B. (1989), Antimicrobial activities of some Ocimum species grown in Rwanda. Journal of Ethnopharmacology, 26, 57-63.

Kéita, S. M.; Vincent, C.; Schmit, J. P.; Arnason, J. T. and Bélanger, A. (2001), Efficacy of essential oil of Ocimum basilicum L. and $O$. gratissimum L. applied as an insecticidal fumigant and powder to control Callosobruchus maculatus (Fab.) [Coleoptera: Bruchidae]. Stored Products Research, 37, 339-349.

Lorenzi, H. and Matos, F. J. A. (2002), Plantas Medicinais no Brasil Nativas e Exóticas. Nova Odessa: Instituto Plantarum de Estudos da Flora.
Madeira, S. V. F.; Matos, F. J. A.; Leal-Cardoso, J. H. and Criddle, D. N. (2002). Relaxant effects of the essential oil of Ocimum gratissimum on isolated ileum of the guinea pig. Journal of Ethnopharmacology, 81, 1-4.

Nakamura, C. V.; Ueda-Nakamura, T.; Bando, E.; Melo, A. F. N.; Cortez, D. A. G. and Dias Filho, B. P. (1999), Antibacterial Activity of Ocimum gratissimum L. Essential Oil. Mem. Inst. Oswaldo Cruz, 94, 675-678.

Ngassoum, M. B.; Essia-Ngang, J. J.; Tatsadjieu, L. N.; Jirovetz, L.; Buchbauer, G. and Adjoudji, O. (2003), Antimicrobial study of essential oils of Ocimum gratissimum leaves and Zanthoxylum xanthoxyloides fruits from Cameroon. Fitoterapia, 74, 284-287.

Offiah, V. N. and Chikwendu, U. A. (1999), Antidiarrhoeal effects of Ocimum gratissimum leaf extract in experimental animals. Journal of Ethnopharmacology, 68, 327-330.

Onajobi, F. D. (1986), Smooth muscle contracting lipidsoluble principles in chromatographic fractions of Ocimum gratissimum. Journal of Ethnopharmacology, 18, 3-11.

Pessoa, L. M.; Morais, S. M.; Bevilaqua, C. M. L. and Luciano, J. H. S. (2002), Anthelmintic activity of essential oil of Ocimum gratissimum Linn. and eugenol against Haemonchus contortus. Veterinary Parasitology, 109, 59-63.

Saito, T.; Hayamizu, K.; Yanagisawa, M.; Yamamoto, O.; Wasada, N.; Kinugasa, S.; Tanabe, K. and Tamura, T. (2004), Integrated Spectral Data Base System for Organic Compounds. Available at: http://www.aist.go.jp/RIODB/SDBS/. Accessed in: 30 Sept., 2004.

Silva, M. G. V.; Craveiro, A. A.; Matos, F. J. A.; Machado, M. I. L. and Alencar, J. W. (1999), Chemical variation during daytime of constituents of the essential oil of Ocimum gratissimum leaves. Fitoterapia, 70, 32-34.

Still, W. C.; Kahn, M. and Mitra, A. (1978), Rapid chromatographic technique for preparative separations with moderate resolution. J. Org. Chem., 43, 2923-2925.

Vieira, R. F.; Grayer, R. J.; Paton, A. and Simon, J. E. (2001), Genetic diversity of Ocimum gratissimum L. based on volatile oil constituents, flavonoids and RAPD markers. Biochemical Systematics and Ecology, 29, 287-304. 